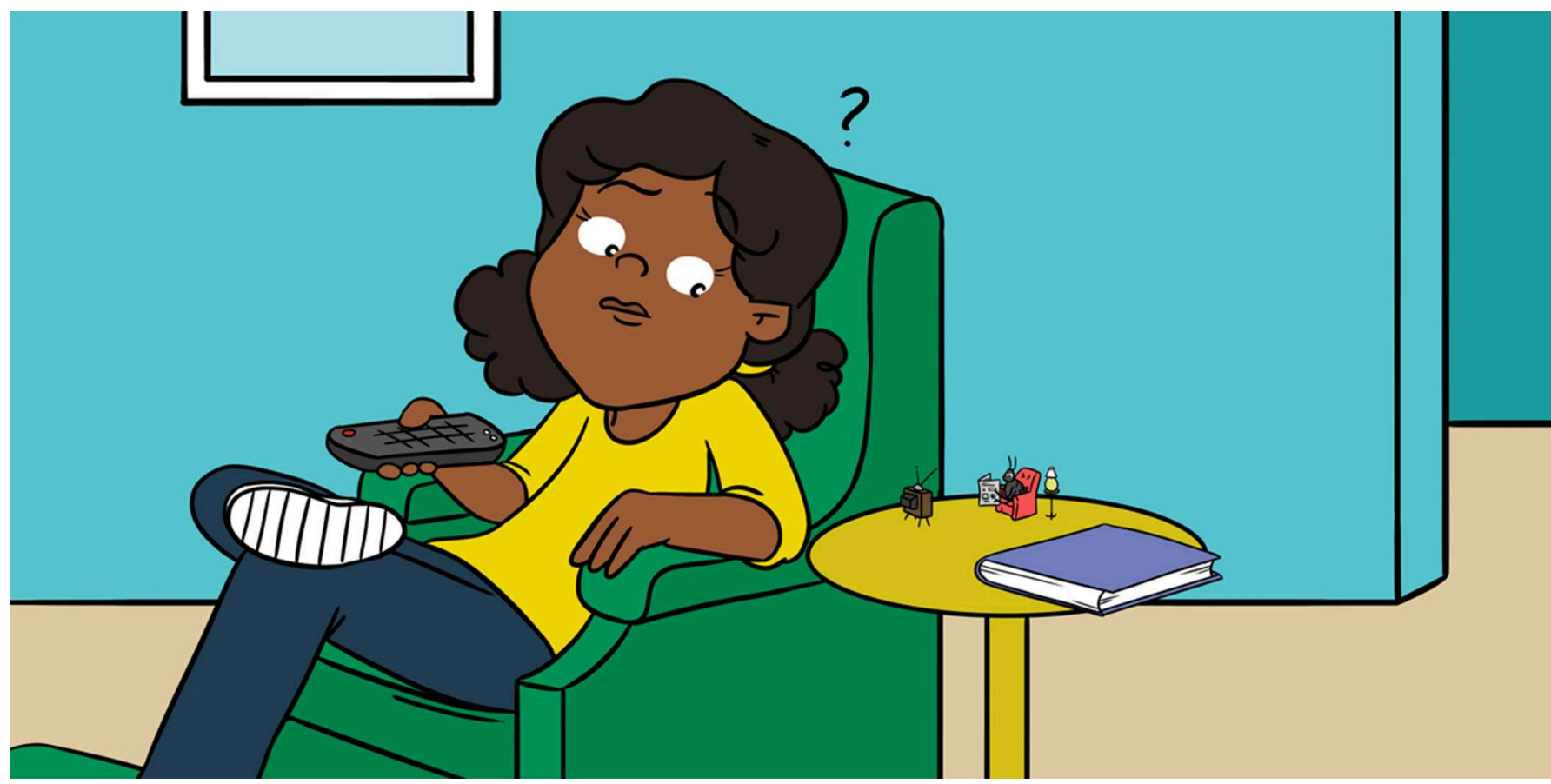

\title{
SHARING YOUR HOME WITH ARTHROPODS
}

\section{Matthew Alan Bertone *}

Department of Entomology and Plant Pathology, North Carolina State University, Raleigh, NC, United States

YOUNG REVIEWERS:

MIDDLE

SCHOOL

CLASSROOM

AGES: 11-12
Arthropods are animals that are found throughout the world, from deserts to mountain tops, all the way down to the bottom of the oceans. In fact, Arthropoda is the most diverse group of animals known, with well over 1.2 million described species [1]. Included in this group are many familiar organisms, some of which you may see on a daily basis. For example, animals like beetles, moths, flies, and spiders (to name a few) are abundant wherever humans live. Many arthropods even live with humans in their homes! To better understand what types of arthropods live in homes, we conducted a survey of all the arthropods we could find in North Carolina (USA) [2] and discovered a lot of interesting creatures.

\section{A HISTORY OF LIVING TOGETHER}

Throughout history, we humans have created places in which to stay. As these living places became permanent, they transformed from shelters into homes. Once we settled and began storing food and keeping livestock (sometimes in the home!) other animals began to find shelter in our homes too, using the resources we provided. For 
Figure 1

Arthropod pests that live on the food in our kitchens: (A) granary weevil (Sitophilus), (B) grain beetle (Oryzaephilus), (C) flour beetle (Tribolium), (D) Indianmeal moth adult (Plodia interpunctella) and (E) larva, and (F) vinegar fly (Drosophila)

\section{ARTHROPOD}

A type of animal in the phylum Arthropoda that has certain characteristics including a segmented body, an exoskeleton, and jointed legs; examples include insects, spiders, mites, crustaceans, and millipedes/centipedes.

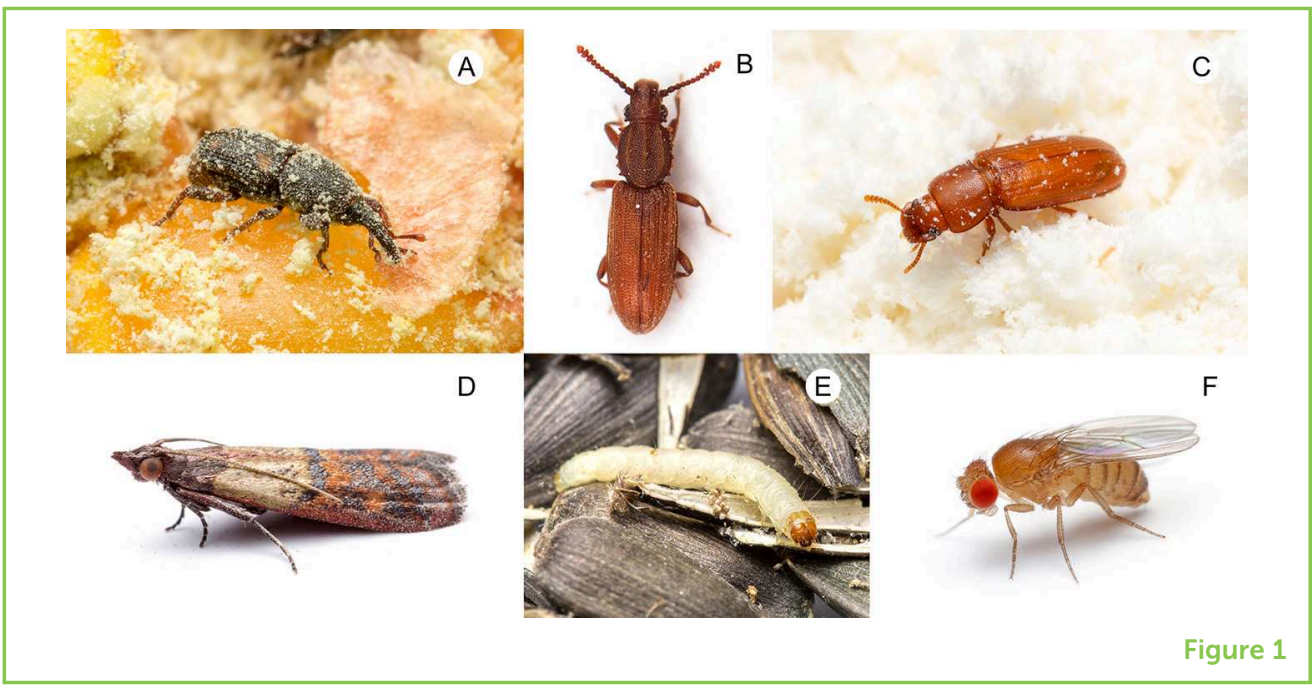

example, large bins or loose bags of corn or rice attracted beetles that fed and bred in this stored food, a perfect habitat where they could live within an almost endless supply of nutrients. So began a relationship between humans and arthropods, organisms, such as beetles, moths, flies and spiders, and this relationship has existed for tens of thousands of years. We know this because we can find many insects in archaeological digs of ancient homes [3, 4].

\section{WHAT IS IN YOUR KITCHEN?}

One of the places arthropods can be found in our homes is in our food. Many of the same species of arthropods collected from ancient sites can still be found in homes today, even in some of the same foods. Granary weevils (Figure 1A), grain beetles (Figure 1B), flour beetles (Figure 1C), and drugstore beetles are all distantly related to each other and have evolved similar habits. Several types of moths (including the Indianmeal moth; Figures 1D,E) also feed on our food products, even chocolate! These species probably evolved in other animal nests before moving into human homes-which was probably an easy transition for them. Fruit flies are another common group of arthropods seen in kitchens (Figure 1F). Although they seem to be attracted to fruit, it is actually the decaying conditions of the food that attracts them, and this is one of the reasons many entomologists (scientists who study insects) prefer to call them vinegar flies (they use the term "fruit flies" for those groups that attack fresh fruit still on the plant). The fly larvae feed on the yeast, mold, and bacteria in the decaying vegetable matter. Yes, you have yeast, mold and bacteria in your home, too-it is not just larger organisms that share your space, but a whole food web, including microorganisms [5]. 


\section{Figure 2}

Scavengers around the home: (A) carpet beetle (Anthrenus) adult and (B) larva, (C) silverfish (Lepismatidae), (D) book louse (Liposcelididae). Bathroom inhabitants include: (E) moth/drain fly (Psychodidae), and (F) springtail (Entomobryidae)

\section{FAMILY}

In taxonomy, a family is a group of organisms classified together because they share certain traits with each other; families are one of the most important taxonomic groups for entomologists to use to discuss groups of insects and other arthropods.

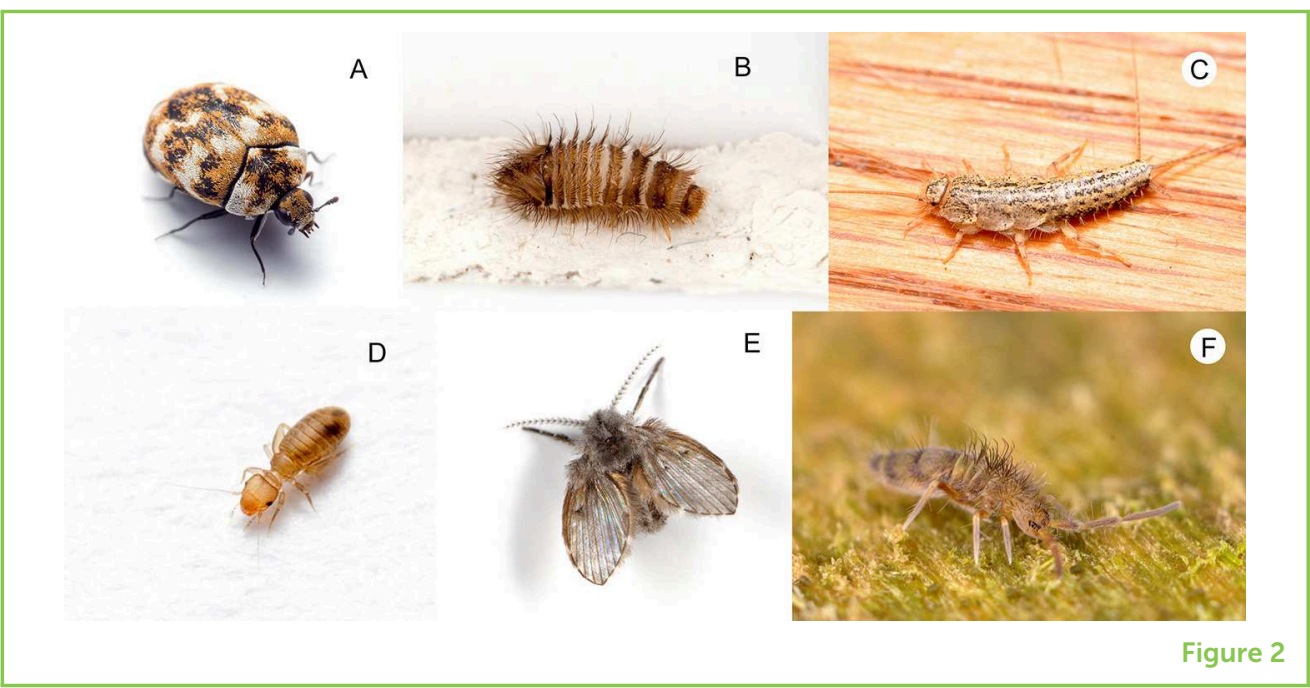

\section{CRAWLING AROUND YOUR FLOORS AND CARPETS}

If you look around your house closely enough, searching the fibers of your carpet and crawling along the edges of a room, you will no doubt find carpet beetles (family Dermestidae; Figures 2A,B), mostly as larvae. These insects were found in all 50 (100\%) of the homes we sampled. They are referred to as carpet beetles because of their preference for wool and animal fur, materials from which we used to make all rugs and carpets. They do not feed on the new, artificial fibers that rugs are made of these days, but they do find enough hair, feathers, fingernails, dead insects, and other food substances to survive for long periods of time in our homes. You may not notice the actively feeding larvae, but in the spring, you can often see the small, colorful adults on windowsills trying to escape the home. Carpet beetles are not the only arthropods scurrying around looking for these types of food-silverfish (Figure 2C) and book lice (Figure 2D) also feed on these items, and can breed and maintain populations in a home indefinitely.

\section{BATHROOM BUDDIES}

With sinks, toilets, and showers, bathrooms usually have more moisture than other rooms in the home. This provides an environment for some of the more specialized arthropods. Drain or moth flies (Figure 2E) can be common because their larvae live in pipes, feeding on the organic matter that builds up in plumbing. You may notice the small, fuzzy adults patrolling the walls of your bathroom. Tiny, jumping arthropods called springtails (Figure 2F) can also be abundant in bathrooms, relying on the humidity there to survive. They feed on molds and mildews (among other things), which are another group of organisms commonly found in homes. 
Figure 3

Arthropod predators

found in the home: (A) cobweb spiders

(Theridiidae), (B) cellar spider (Pholcidae) with prey, and (C) house centipede (Scutigera coleoptrata). Parasites and pests found in the home: (D) cat flea (Ctenocephalides felis), (E) bed bug (Cimex lectularius), and (F) German cockroach (Blattella germanica) with egg case.

\section{PEST}

An organism that is doing some sort of harm to humans or causing problems to human activities or their property (including pets, livestock, or plants).

\section{PARASITE}

An organism that gains its nutrition by feeding on another organism, usually without killing the host organism but often affecting it in a negative way.

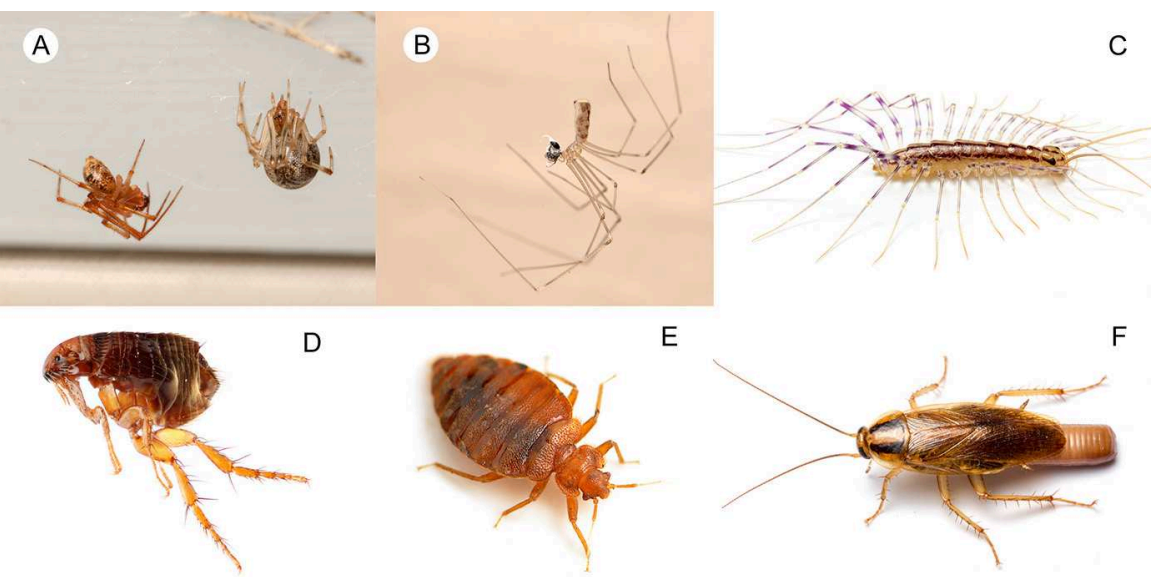

Figure 3

\section{SPIDERS ARE ALL OVER-BUT THAT IS NOT A BAD THING}

The previous arthropods may seem pretty harmless or, at the worst, we may think they are pests because they are annoying. But spiders tend to create a lot of fear in people. This is due to the fact that almost all spiders are venomous, and some have large enough fangs to bite humans. However, other than a few species, most spiders are harmless, avoid humans, and are beneficial as predators of pests and parasites. This is good news, because in our study we found that two families of spiders, cobweb spiders (Figure 3A) and cellar spiders (Figure 3B), were found in 100 and $84 \%$ of homes, respectively. In fact, we found evidence of cobweb spiders in $65 \%$ of the rooms we sampled. Spiders are very good at surviving for long periods of time without food, and can live in the less-than-ideal environment that houses provide. Spiders are not the only predators to become accustomed to homes. House centipedes (Figure 3C), or "thousand-leggers" may be even more terrifying to people. These many-legged arthropods can thrive indoors where the humidity is right. Their extreme speed and large size (over 1 inch) make them a bit scary, but these centipedes are not aggressive and enjoy hunting things like cockroaches and flies.

\section{HOME PARASITES AND PESTS}

Not all arthropods in our homes eat our scraps or other arthropods. Some are there to feed on us or our pets. A lot of parasites get their nourishment from the blood of vertebrates. In homes, these most often are fleas (mostly the cat flea, which also attacks dogs; Figure 3D) or bed bugs (Figure 3E). Bed bugs have become much more common in recent years. In some areas of the world, kissing bugs (in the family Reduviidae) live in homes and come out at night to feed on us-they can even transmit serious diseases. Even if they do not live inside, some parasites follow us indoors, such as mosquitoes and ticks. There are 
even arthropods that are associated with certain other animals that might live in our homes, for example bat bugs that normally live on bats in our attics, and the bugs that live on birds called chimney swifts. Bat bugs and chimney swift bugs are both related to bed bugs, and they will feed on humans, temporarily, when bats and chimney swifts are not available.

Arthropod pests in homes can be bad for our health in other ways. Some flies, referred to as filth flies because they breed in dung or decaying matter, can transfer harmful microorganisms to us when they land on food or other surfaces. Perhaps the most well-known group of home insect pests are cockroaches, and a few species can be common in some homes. One species, the German cockroach (Figure 3F), is so well-adapted to homes that it is not found out in nature. Cockroaches, in addition to being dirty and bothersome, are known to produce gut proteins that, when excreted, become allergens that can cause severe issues in humans, including asthma [6].

\section{CONCLUSIONS}

Although your home may be teeming with the arthropod life described in this article, that does not mean your lifestyle is unclean or that these animals are taking over. On the contrary, it is very typical to have these arthropods in your home, and their total biomass, for example if you weighed them all, is very, very small. Also, while many of the arthropods we found in our survey were well-adapted to living in homes, a large portion of the arthropods we collected were accidental visitors from the outdoor environment. These temporary guests often get trapped in homes, and either become prey for predators or die and become food for scavengers. Their bodies become an important source of food for indoor organisms. In the end, you will likely go about your days without noticing most of the arthropods that live in your home. Still, they represent an indoor community that has persisted with humans and will likely flourish as long as humans build homes. If a pest species is present, there are professionals who can help manage these pests. But for most other groups of arthropods, if they are found in your home and unwanted, simply capture them alive and let them go outdoors!

\section{REFERENCES}

1. Zhang, Z.-Q. 2011. "Phylum arthropoda von Siebold, 1848," in Animal Biodiversity: An Outline of Higher-Level Classification and Survey of Taxonomic Richness. Zootaxa, Vol. 3148, ed Z.-Q. Zhang (Auckland: Magnolia Press). p. 99-103.

2. Bertone, M. A., Leong, M., Bayless, K. M., Malow, T. L., Dunn, R. R., and Trautwein, M. D. 2016. Arthropods of the great indoors: characterizing diversity inside urban and suburban homes. PeerJ 4:e1582. doi: 10.7717/peerj.1582 
3. Panagiotakopulu, E., and Buckland, P. C. 1991. Insect pests of stored products from late bronze age Santorini, Greece. J. Stored Prod. Res. 27:179-84.

4. Panagiotakopulu, E. 2004. Dipterous remains and archaeological interpretation. J. Archaeol. Sci. 31:1675-84. doi: 10.1016/j.jas.2004.04.008

5. Dunn, R. R., Fierer, N., Henley, J. B., Leff, J. W., and Menninger, H. L. 2013. Home life: factors structuring the bacterial diversity found within and between homes. PLOS ONE 8:e64133. doi: 10.1371/journal.pone.0064133

6. Gore, J. C., and Schal, C. 2007. Cockroach allergen biology and mitigation in the indoor environment. Annu. Rev. Entomol. 52:439-63.

doi: 10.1146/annurev.ento.52.110405.091313

SUBMITTED: 25 April 2019; ACCEPTED: 30 August 2019;

PUBLISHED ONLINE: 18 September 2019.

EDITED BY: Frederique Carcaillet, Université de Montpellier, France

CITATION: Bertone MA (2019) Sharing Your Home With Arthropods. Front. Young Minds 7:122. doi: 10.3389/frym.2019.00122

CONFLICT OF INTEREST STATEMENT: The author declares that the research was conducted in the absence of any commercial or financial relationships that could be construed as a potential conflict of interest.

COPYRIGHT () 2019 Bertone. This is an open-access article distributed under the terms of the Creative Commons Attribution License (CC BY). The use, distribution or reproduction in other forums is permitted, provided the original author(s) and the copyright owner(s) are credited and that the original publication in this journal is cited, in accordance with accepted academic practice. No use, distribution or reproduction is permitted which does not comply with these terms.

\section{YOUNG REVIEWERS}

MIDDLE SCHOOL CLASSROOM, AGES: 11-12

We are a middle school classroom in Reno, NV.

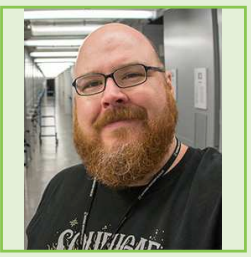

\section{AUTHOR}

\section{MATTHEW ALAN BERTONE}

I am the entomologist with the Plant Disease and Insect Clinic in the Department of Entomology and Plant Pathology at NC State University. My background is mostly in arthropod systematics and evolution, with an emphasis on true flies (Diptera), but I have interests in most groups of organisms. I am also a macro photographer, mainly of arthropods and invertebrates. *matt_bertone@ancsu.edu 